\title{
Aggregate properties of a typic ustipsamment under different tillage practices in Maiduguri, Nigeria.
}

\author{
${ }^{1}$ Sauwa, M.M., ${ }^{2}$ Chiroma, A.M., ${ }^{1}$ Dikko, A.U., ${ }^{2}$ Waniyo, U.U. and ${ }^{3}$ Aisha, B. \\ ${ }^{1}$ Department of Soil Science and Agricultural Engineering, Faculty of Agriculture, Usmanu \\ Danfodiyo University, PMB 2346, Sokoto,Nigeria. \\ ${ }^{2}$ Department of Soil Science, Faculty of Agriculture, University of Maiduguri, Nigeria. \\ ${ }^{3}$ Department of Farming Systems, Lake Chad Research Institute Maiduguri, Borno State, \\ Nigeria.
}

Corresponding author Email: mmsauwa4U@yahoo.com

\begin{abstract}
Soil structure is of fundamental significance to the productivity of agricultural soils as it influences their water status, workability, resistance to erosion likewise crop growth and development. The effect of three tillage systems: no-tillage (NT), reduce tillage (RT) and conventional tillage (CT)) on the structural stability of a sandy loam soil in semiarid north eastern Nigeria, was evaluated after 9-15 years of management. At the end of growing season of 2010, triplicate undisturbed core samples $(10.8 \mathrm{~cm}$ in diameter and $12 \mathrm{~cm}$ height) were obtained at two soil depths $(0-15 \mathrm{~cm}$ and $15-30 \mathrm{~cm})$, screened through a $4 \mathrm{~mm}$ mesh, air dried and used for aggregate stability determinations. At the end of the study, aggregate stability of the soil measured as MWDD, MWDW, WSI, DR, and ASC on average was greatest for the NT treatment except MWDD and least for the CT treatment, while the RT treatment recorded intermediary values. Most of the structural stability indices measured were found to strongly correlate with OC, $\mathrm{K}$ and TN content of the soil. In general, however, structural stability of the soil decreased with depth irrespective of tillage method. We concluded that, the conservation tillage practices ( NT and RT ) are better soil management options for improving structural stability of the soil, compared to the conventional (CT) treatment.

Key words: Tillage, Soil structure, Structural stability, Stability indices, Conservation tillage, Conventional Tillage
\end{abstract}

\section{INTRODUCTION}

Soil structure is of fundamental significance to the productivity of agricultural soils as it influences several other properties. Soil structure plays important role in water and air supply to roots, root elongation, nutrient availability and macro $f$ auna activity (Milton da Veiga et al., 2009). A good soil structure also influences water status of a soil, its workability and resistance to erosion, likewise crop growth and development (Piccolo and Mbagwu, 1999). Processes and mechanisms involved in soil aggregation are complex with intricate feedback mechanisms. Soil aggregation can be improved by management practices that decrease agroecosystem disturbance, improve soil fertility, increase organic inputs, increase plant cover, and decrease soil organic carbon decomposition rate (Singh and Kaur, 2012). Greater water stable aggregates had been reported in reduced and no-till systems relative to the conventional system (Barzeger et al. ,2004). This increase in aggregate stability of conservation tillage systems (reduced and/or no-till) had been related to increased organic carbon content (Barzeger et al. ,2004; Golchin and Asgari, 2008) and less mechanical disturbance by tillage implements (Mbagwu and Bazzoffi, 1989).

Water stable aggregates in the upper few $\mathrm{mm}$ of the soil layer may improve germination and seedling establishment by reducing crusting and erosion and by allowing entry of water and air through the soil. In addition, soil structural improvement enhances nutrient cycling, water availability and biodiversity while reducing water and wind erosion (Singh and 
Kaur, 2012). Knowledge of structural stability of soils therefore becomes paramount for sustainable agriculture, particularly in predominantly fragile coarse textured soils of semi arid environments. Knowledge of structural stability of a soil for agricultural uses is achieved through determination of its aggregate stability (Osuji and Onweremadu, 2007). Several indicators can be use to measure the stability of soil structure. These indicators, however, vary in terms of sensitivity and capacity of discriminating among soils and treatments (Tedeschi, 2000). Therefore, good knowledge of tillage treatments effect on soil structural stability could best be achieved through measurement of several stability indices.

This study is aimed at evaluating the effect of different tillage practices on structural stability of the soil using several stability indices.

\section{MATERIALS AND METHOD}

The Study Area: The study was carried out in Maiduguri, north east Nigeria. Climate of Maiduguri is semi arid with long-term mean annual rainfall (19611990) of $553 \mathrm{~mm}$. Rainfall distribution is unimodal, starting on the average in Mid June and las ting until the end of September (Grema and Hess, 19 94). Five sites were used for the study. The sites were selected based on their land use history. Soils of the study area are Sandy loam Typic ustipsamment (Rayar ,1984). GPR equipment (12 channel GPS etrex, courtesy GARMIN Corporation 1999-2002) was used in determining coordinates of the sites.

Treatments and Experimental design: The experiment was carried out using randomize complete block design (RCBD) with three treatments and five replications. Statistix 8.0 ( version 2005) analytical software was used in analyzing data obtained. Three tillage practices namely no-tillage (NT), reduce tillage (RT) and conventional tillage (CT) were evaluated on each site. The summary of location and land use history of the selected sites are as follows:

SITE1: University of Maiduguri Teaching and Resear ch Farm $\left(11^{\circ} 54^{\prime} \mathrm{N}, 13^{\circ} 5^{\prime} \mathrm{E}\right)$.

An uncultivated land (left fallow) for a period of 9-15 years was sampled at this site. The dominant plant species in this area are Andropogon gayanum, Cenchrus biflorus, and scattered Azadirachta indica trees. Adjacent to this field, a conventionally tilled plot continuously sown to groundnut and millet for about
9-15 years and a reduced-till plot continuously sown to groundnut and cowpea for a period of 9-15 years were also sampled. Tillage practices in the cultivated fields involved 1-2 tractor harrow passes and hand hoe cultivation per season for conventional tillage (CT) and reduced tillage (RT) treatments respectively. Further, NPK and Phosphatic fertilizers are commonly applied by farmers.

SITE 2: Livestock Farm, University of Maiduguri $\left(11^{\circ} 47.6^{\prime} \mathrm{N}, 13^{\circ} 12.5^{\prime} \mathrm{E}\right)$. In this site, an uncultivated land (left fallow) for a period of 915 years and an adjacent conventionally tilled plot continuously sown to Maize and Cowpea about 9-15 years were sampled. A nearby reduced- till plot sown to Groundnut and Cowpea for 9-15 years was also sampled. The Dominant plant species in this area are Senna obtusfolia, Achyranthes asper L., and scattered Balanities aegyptiaca trees. Tillage practices performed in the cultivated fields were same as those in site 1.

SITE3: Kwayam Village, off University of Maiduguri $\left(11^{\circ} 47.9^{\prime} \mathrm{N}, 13^{\circ} 12.6^{\prime} \mathrm{E}\right)$.

At this site, uncultivated land ( left fallow) for 9-15 years and an adjacent reduced- till plot sown to Millet and Cowpea for about 9-15 years were sampled. Adjacent to the reduced- till plot, a conventionally tilled plot continuously sown to Maize and Cowpea for 9-15 years was also sampled. The dominant plant species in this area are Cenchrus biflorus, Imperata cylindrica, and scattered Piliostigma reticulatum and Faidherbia albida trees. Tillage practices in the cultivated plots were same as those in site 1.

SITE 4: Old Malumbrari Primary School, Maiduguri $\left(11^{\circ} 47^{\prime} \mathrm{N}, 13^{\circ} 12.7^{\prime} \mathrm{E}\right)$.

In site 4, a soil uncultivated (left fallow) for about 9-15 years and a conventionally tilled plot adjacent to the uncultivated plot continuously sown to Groundnut and Cowpea for about 9-15 years were sampled. Adjacent to the conventional plot, a reduced- till plot continuously sown to Groundnut and Cowpea for 915 years was also sampled. The Dominant plant species in this area are Senna obtusfolia, Achyranthes asper L., Zizuphus mauritiana and Balanities aegyptiaca trees. The same tillage practice $\mathrm{s}$ were carried out as in site 1.

SITE 5: University of Maiduguri Commercial Farm $\left(11^{\circ} 47.61^{\prime} \mathrm{N}, 13^{\circ} 13.04^{\prime} \mathrm{E}\right)$.

At this site, a field uncultivated (left fallow) for a period of 9-15 years was sampled. Adjacent to this 
Agric. Biol. J. N. Am., 2013, 4(4): 234-242

plot, conventionally tilled plot continuously sown to Millet and Cowpea for about 9-15 years and a reduced- till plot continuously sown to Millet and Cowpea for 9-15 years were also sampled. The dominant plant species in this area are Cenchrus biflorus, Achyranthes asper L., Senna obtusfolia, and scattered Balanities aegyptiaca trees. The same tillage practices for the cultivated plots in site 1 were also carried out in this site.

The five selected sites were within close proximity of one another, and within each selected site treatment plots were located within $40-60 \mathrm{~m}$ of one another and had same parent material (Aeolian sand) and similar textural composition (Table 4). At the end of growing season of 2010 (November) composite core samples (10.8 cm in diameter and $12 \mathrm{~cm}$ height) were collected at $(0-15$ and $15-30 \mathrm{~cm})$ soil depth for the determination of aggregate stability indices of the soil. The soil aggregate stability was determined using the following methods:

1 Mean -weight diameter of dry aggregates (MWDD): This was determined according to the method of Kemper and Chepil (1965). Which involved vibrating on a mechanical shaker for 10 minutes a known quantity of dry soil (previously sieved through a $4 \mathrm{~mm}$ mesh) on top of nest of sieves of diameter 2 , $1,0.5$, and $0.25 \mathrm{~mm}$ and determining the mass of aggregates on each sieve that resisted breakdown. All aggregate fractions were then collected, weighed, remixed and used for wet-sieving analysis.

2 Mean-weight diameter of wet aggregates (MWDW): This was determined according to the method of Kemper (1965) using the remixed dry aggregates from (1) above. In this procedure the soil is presoaked for 10 minutes on topmost sieves in a nest as in (1) above, then vertically oscillated for 20 minutes at the rate of 1 oscillation per second, oven drying the resistant aggregates and recording their masses.

3 Aggregate silt-plus-clay (ASC \%): This is defined as the difference between silt + clay in calgon-dispersed and that in water-

dispersed soil samples (Middleton, 1930).

4 Water- stability index (WSI \%): Water stability index was computed as $100(1-A / B)$. Where $A$ is percentage of aggregates which passed a $0.20 \mathrm{~mm}$ sieve in 5 minutes after shaking at the rate of 60 oscillations per minute at room temperature and $B$ is the percentage that passed after 60 minutes under the same conditions (Malquori and Cecconi, 1962). 5 Dispersion ratio (DR): Dispersion ratio was computed as $\mathrm{DR}=(\mathrm{A} / \mathrm{B}) \times 100$. Where $\mathrm{A}=$ Percent silt + clay in water-dispersed sample, and $B=$ Percent silt + clay in calgon-dispersed sample ((Middleton, 1930).

Chemical properties of the soil were determined according to methods of Page et al. (1982). Organic carbon $(\mathrm{OC})$ by wet oxidation method, total nitrogen (TN) kjeldahl procedure, calcium (Ca) and magnesium (Mg) EDTA titration method, sodium $(\mathrm{Na})$ and potassium (K) by flame photometry. Exchangeable acidity (EXA) by titration method, electrical conductivity (EC) by conductivity meter, $\mathrm{pH}$ using $\mathrm{pH}$ meter. While ESP and SAR were determined by the following relations:

$\mathrm{ESP}=\mathrm{Na} / \mathrm{CEC} \times 100, \mathrm{SAR}=\mathrm{Na} \div \sqrt{\mathrm{Ca}}+\mathrm{Mg} / 2$.

\section{RESULTS AND DISCUSSION}

Mean weight diameter of dry aggregate (MWDD): The percentages of aggregates in each size class at the two depths of measurement are presented in Table 1. Significant $(p \leq 0.05)$ differences in the proportion of aggregates of various sizes in most cases were observed at both surface $(0-15 \mathrm{~cm})$ and sub surface $(15-30 \mathrm{~cm})$ soil depths. The conservation tillage systems (NT and RT) recorded significantly $(p \leq 0.05)$ higher values of MWDD in most of the size classes, compared to the CT treatment at both surface and sub surface soil depths (Table 1). In general, however, there was a significant reduction $(p<0.05)$ in the proportion of aggregate size $>0.25$ $\mathrm{mm}$ (macro aggregates) by the CT treatment at both surface and sub surface soil depths. The RT and NT treatments recorded higher macro aggregate (MA) values at both surface (27.9 and 23.4) and sub surface (25.2 and 24.4) soil layers respectively, compared to the CT treatment (16.81 and 21.77) Table 1. It is however striking that the RT treatment recorded the highest MA values for both surface and sub surface soil depths compared to the NT treatment, despite higher OC content of the NT treatment. However, good correlation between MA of dry aggregates (MAD) and magnesium (Mg) content of the soil at the surface and potassium $(K)$ content at the sub surface soil depths was observed (Table 2 ), suggesting the influence of $\mathrm{Mg}$ and $\mathrm{K}$ on dry aggregate stability of the soil. Generally, as MA represents larger clods, soil erosion by wind and water could be reduced in the RT and NT treatments compared to the CT treatment, as soil structural stability is known to be a key indicator of resistance of tropical soils to erosion (Bryan et al.,1989). 
Mean weight diameter of wet aggregate (MWDW): The proportion of mean weight diameter of wet aggregates (MWDW) also known as water stable aggregates, were significantly $(p \leq 0.05)$ influenced by tillage systems. The results of tillage effect on MWDW are presented in Table 1. On average, the conservation tillage systems (NT and RT) had greater water stable aggregates of various sizes at both surface $(0-15 \mathrm{~cm})$ and sub surface $(15-30 \mathrm{~cm})$ soil depths, compared to the conventional (CT) treatment. Similar results were obtained by Barzeger et al. (2004). There was also significant $(p<0.05)$ reduction in the proportion of wet aggregate sizes $>$
$0.25 \mathrm{~mm}$ (macro aggregates) by the CT treatment at both surface and sub surface soil depths, relative to the NT and RT treatments (Table 1). The NT treatment recorded highest macro aggregate (MA) of wet aggregates at both surface $(28.3 \%)$ and sub surface $(26.5 \%)$ soil depths followed by the RT treatment (26.8 and $23.4 \%$ ), while the CT treatment recorded the least (21.7 and $17.9 \%)$ for surface and sub surface soil depths respectively (Table 1 ). This was expected as intensive cultivation had been reported to disrupt MA and decreases the stability of soil aggregates by promoting organic matter loss and deteriorating soil structure (Six et al., 2000a).

Table 1. Mean weight diameter of dry (MWDD) and wet (MWDW) aggregates as affected by tillage systems

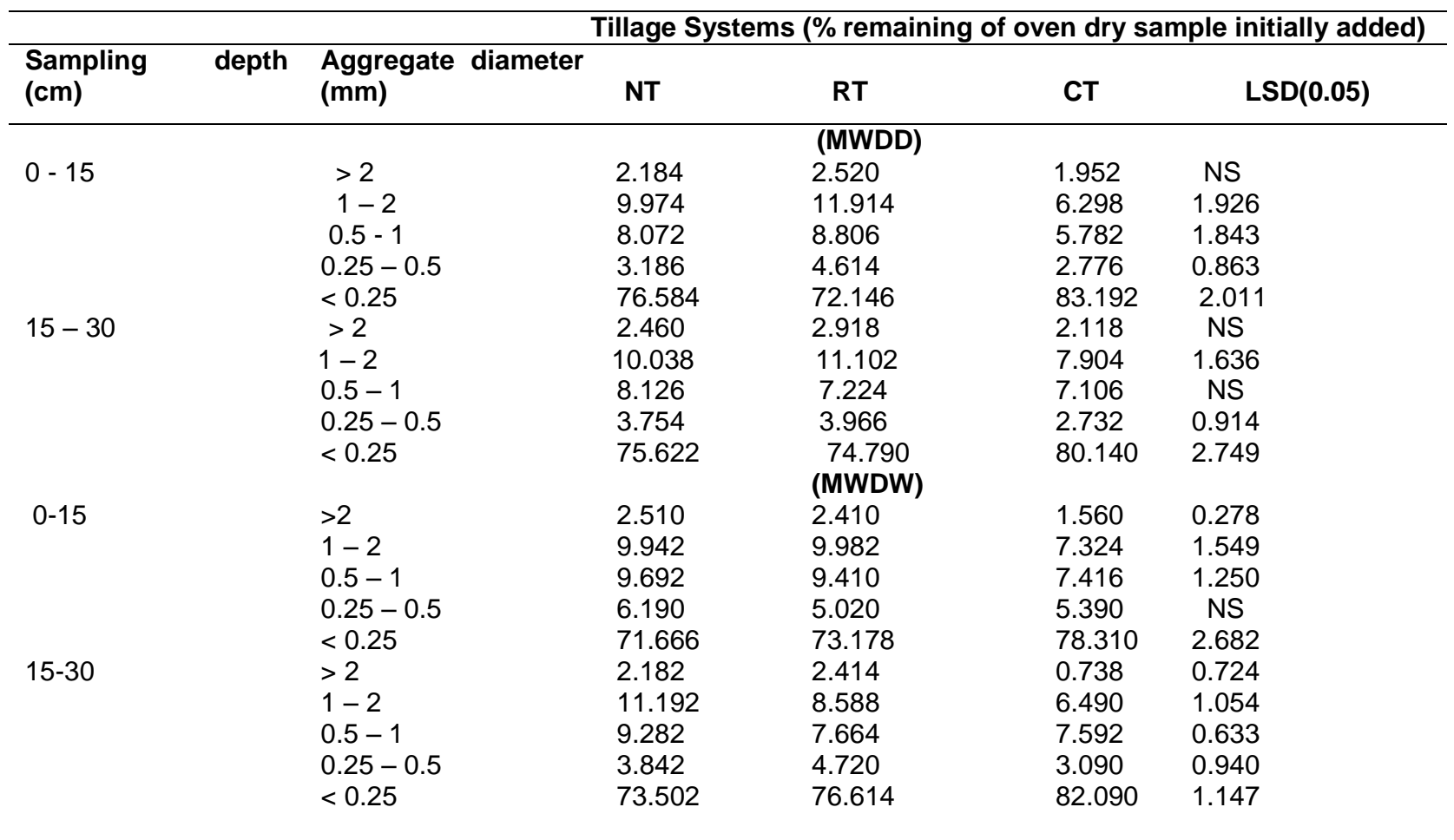

${ }^{1}$ NT-no till, RT-reduce till, CT-Conventional tillage

${ }^{2}$ NS- not significant at $\mathrm{p} \leq 0.05$

Generally, MA decreased with depth irrespective of tillage treatment (Table 1), which could be attributed to decreased organic carbon (OC) content with depth. Good correlation between MA of wet aggregates (MAW) and $\mathrm{OC}, \mathrm{pH}$, total nitrogen (TN), magnesium ( $\mathrm{Mg}$ ) and potassium $(\mathrm{K})$ content of the soil at surface $(0-15 \mathrm{~cm})$ soil depth was observed, while a negative correlation was observed between exchangeable sodium percentage (ESP) and MAW at surface soil depth (Table 2). However, at the sub surface $(15-30 \mathrm{~cm})$ soil depth, only OC and potassium (K) correlated positively with MAW. Similar correlation between $\mathrm{OC}, \mathrm{pH}, \mathrm{TN}$ and similar structural stability indices at surface $(0-15 \mathrm{~cm})$ soil depth were reported by Osuji and Onweremadu (2007) in some coarse textured soils of southeastern Nigeria. The regression equation relating $O C$ and MAW at surface soil depth is given by :

$M A=18.94+26.550 C, r^{2}=0.78$ 
The above equation shows that, MAW increases by 26.5 (\%) for every unit increase in OC content of the soil. Several workers had related better water stable aggregates to higher OC contents of treatments ( Chiroma et al., 2006; Osuji and Onweremadu, 2007; Golchin and Asgari, 2008). Soil organic matter (here reflected as $\mathrm{OC}$ ), promotes aggregate stabilization because organic binding agents may have transient, temporary, or persistent effect, depending on which binding agent is involved in stabilization (Tisdall and Oades, 1982). Practices that decreases aggregate strength (reflected by decreased MA) had been reported to cause slaking of soil aggregates upon rainfall events, clogging soil pores, thereby decreasing water transmission through soils (Pikul and Aase, 1995 , Mbagwu and Auerswald, 1999), which in turn, accelerates soil erosion problems and decreases water availability to crops (Folorunso, 1986; Franzluebbers, 2002).

Effect of Tillage Systems on other Stability Indices: Tillage effect on water stability index (WSI), aggregated silt + clay (ASC \%) and dispersion ratio (DR) are presented in Table 3. Significant effect ( $p \leq$ 0.05 ) of tillage systems on WSI was observed at both surface $(0-15 \mathrm{~cm})$ and sub surface $(15-30 \mathrm{~cm})$ soil depths. The NT and RT treatments recorded higher WSI values at both surface and sub surface soil depths, relative to the CT treatment (Table 3). Similar results were obtained by Mbagwu and Bazzoffi (1989). The WSI of the soil positively correlated with soil $\mathrm{pH}, \mathrm{OC}, \mathrm{TN}, \mathrm{C}: \mathrm{N}, \mathrm{Mg}$ and $\mathrm{K}$ contents of the soil, while ESP correlated negatively (Table 2). The regression equation relating $\mathrm{WSI}$ of the soil and OC content at surface soil depth is given by :

$W S I=29.07+107.900 C, r^{2}=0.56$

The above equation showed that WSI increases by $107.90(\%)$ for every unit increase in OC content of the soil. Tedeschi (2000) also reported greater stability of soil due higher WSI in Italy. Tillage effect on the dispersion ratio (DR) was only significant $(p \leq 0.05)$ at the sub surface (15-
$30 \mathrm{~cm}$ ) soil depth (Table 3). However, conservation tillage practices (NT and $\mathrm{RT}$ ) recorded lower values compared to the conventional (CT) treatment at both surface $(0-15 \mathrm{~cm})$ and sub surface $(15-30 \mathrm{~cm})$ soil depths, indicating greater structural stability of the NT and RT treatments relative to the CT treatment. Soil OC strongly correlated (negatively) with DR of the soil at surface $(0-15 \mathrm{~cm})$ soil depth (Table 2), implying the greater the OC content of the soil, the lower the DR, and thus, the greater the structural stability. Similar results had been reported by Mbagwu and Bazzoffi (1989). The regression equation relating $\mathrm{DR}$ and $\mathrm{OC}$ content of the soil at surface $(0-15 \mathrm{~cm})$ depth is presented as:

$D R=92.66-49.230 \mathrm{C}, r^{2}=0.41$

The equation above implies that the DR decreased by 49.23 (\%) for every unit increase in OC content of the soil.

Tillage systems did not affect aggregated silt + clay (ASC \%) content of the soil at both surface $(0-15 \mathrm{~cm})$ and sub surface $(15-30 \mathrm{~cm})$ soil depths. The values obtained were not significantly $(p \leq 0.05)$ different between tillage treatments (Table 3 ). However, the conservation tillage (NT and $\mathrm{RT}$ ) treatments recorded higher values compared to the conventional (CT) treatment at both surface and sub surface soil depths. The results were in line with findings of Mbagwu and Bazzoffi (1989).

Good positive correlation between ASC (\%) and OC, $\mathrm{TN}, \mathrm{K}$ and $\mathrm{pH}$ content of the soil at surface $(0-15 \mathrm{~cm})$ depth was observed (Table 2). The regression equation relating OC and ASC (\%) contents of the soil at surface soil layer was obtained as:

$\operatorname{ASC}(\%)=2.13+15.930 \mathrm{C}, r^{2}=0.45$

The equation above shows good relationship between OC and ASC(\%) contents of the soil 
Agric. Biol. J. N. Am., 2013, 4(4): 234-242

Table 2. Pearson Correlation coefficient between some soil chemical properties and aggregate stability indices at 0 15 and $15-30 \mathrm{~cm}$ soil depths

\begin{tabular}{|c|c|c|c|c|c|}
\hline \multirow[t]{2}{*}{ Treatment } & \multicolumn{5}{|c|}{ Aggregate Stability Indices } \\
\hline & MAD & MAW & WSI & DR & ASC \\
\hline \multicolumn{6}{|c|}{ 0-15cm Depth } \\
\hline OC & $0.41^{\mathrm{ns}}$ & $0.72^{\pi \times}$ & $0.75^{\mathrm{nx}}$ & $-0.64^{\pi *}$ & $0.67^{* *}$ \\
\hline TN & $0.40^{\mathrm{ns}}$ & $0.83^{\pi \times x}$ & $0.79^{\pi \times x}$ & $-0.70^{\times \pi}$ & $0.72^{\star x}$ \\
\hline $\mathrm{C}: \mathrm{N}$ & $0.27^{\mathrm{ns}}$ & $0.46^{\mathrm{ns}}$ & $0.54^{*}$ & $-0.48^{\text {ns }}$ & $0.48^{\text {ns }}$ \\
\hline $\mathrm{Ca}$ & $0.05^{\mathrm{ns}}$ & $0.35^{\mathrm{ns}}$ & $0.38^{\mathrm{ns}}$ & $-0.30^{\mathrm{ns}}$ & $0.34^{\mathrm{ns}}$ \\
\hline $\mathrm{Mg}$ & $0.53^{*}$ & $0.62^{\pi \times}$ & $0.56^{*}$ & $-0.38^{\text {ns }}$ & $0.39^{\mathrm{ns}}$ \\
\hline $\mathrm{Na}$ & $-0.09^{\text {ns }}$ & $0.07^{\mathrm{ns}}$ & $0.05^{\mathrm{ns}}$ & $-0.11^{\text {ns }}$ & $0.14^{\mathrm{ns}}$ \\
\hline K & $0.18^{\mathrm{ns}}$ & $0.64^{* \pi}$ & $0.64^{* *}$ & $-0.58^{*}$ & $0.61^{* *}$ \\
\hline $\mathrm{pH}$ & $0.18^{\mathrm{ns}}$ & $0.51^{*}$ & $0.52^{*}$ & $-0.49^{\text {ns }}$ & $0.60^{* *}$ \\
\hline EXA & $0.12^{\mathrm{ns}}$ & $0.01^{\mathrm{ns}}$ & $0.20^{\mathrm{ns}}$ & $0.06^{\mathrm{ns}}$ & $-0.04^{\mathrm{ns}}$ \\
\hline SAR & $-0.36^{\mathrm{ns}}$ & $-0.33^{\text {ns }}$ & $-0.35^{\mathrm{ns}}$ & $0.14^{\mathrm{ns}}$ & $-0.12^{\mathrm{ns}}$ \\
\hline ESP & $-0.49^{\text {ns }}$ & $-0.60^{* *}$ & $-0.62^{* \pi}$ & $0.33^{\mathrm{ns}}$ & $-0.32^{\mathrm{ns}}$ \\
\hline EC & $0.05^{\mathrm{ns}}$ & $-0.08^{\mathrm{ns}}$ & $0.24^{\mathrm{ns}}$ & $-0.09^{\text {ns }}$ & $0.014^{\mathrm{ns}}$ \\
\hline \multicolumn{6}{|c|}{ 15-30cm Depth } \\
\hline OC & $0.42^{\mathrm{ns}}$ & $0.55^{*}$ & $0.70^{* x}$ & $-0.38^{\mathrm{ns}}$ & $0.23^{\mathrm{ns}}$ \\
\hline TN & $0.40^{\mathrm{ns}}$ & $0.45^{\mathrm{ns}}$ & $0.66^{x \times}$ & $-0.25^{\mathrm{ns}}$ & $0.07^{\mathrm{ns}}$ \\
\hline $\mathrm{C}: \mathrm{N}$ & $0.16^{\mathrm{ns}}$ & $0.42^{\mathrm{ns}}$ & $0.37^{\mathrm{ns}}$ & $-0.47^{\mathrm{ns}}$ & $0.47^{\mathrm{ns}}$ \\
\hline $\mathrm{Ca}$ & $-0.13^{\text {ns }}$ & $0.01^{\mathrm{ns}}$ & $-0.21^{\mathrm{ns}}$ & $0.10^{\mathrm{ns}}$ & $-0.13^{\text {ns }}$ \\
\hline $\mathrm{Mg}$ & $0.33^{\mathrm{ns}}$ & $0.43^{\mathrm{ns}}$ & $0.01^{\mathrm{ns}}$ & $-0.04^{\mathrm{ns}}$ & $0.01^{\mathrm{ns}}$ \\
\hline $\mathrm{Na}$ & $0.21^{\mathrm{ns}}$ & 0.08 & -0.03 & $0.38^{\mathrm{ns}}$ & $-0.34^{\mathrm{ns}}$ \\
\hline $\mathrm{K}$ & $0.50^{*}$ & $0.63^{x *}$ & $0.48^{\mathrm{ns}}$ & $-0.24^{\mathrm{ns}}$ & $0.21^{\mathrm{ns}}$ \\
\hline $\mathrm{pH}$ & $0.15^{\mathrm{ns}}$ & $0.26^{\mathrm{ns}}$ & $-0.08^{\text {ns }}$ & $-0.16^{\mathrm{ns}}$ & $0.13^{\mathrm{ns}}$ \\
\hline EXA & $0.08^{\mathrm{ns}}$ & $0.11^{\mathrm{ns}}$ & $0.42^{\mathrm{ns}}$ & $0.03^{\mathrm{ns}}$ & $-0.12^{\mathrm{ns}}$ \\
\hline SAR & $0.05^{\mathrm{ns}}$ & $-0.19^{\text {ns }}$ & $0.04^{\mathrm{ns}}$ & $0.28^{\mathrm{ns}}$ & $-0.20^{\mathrm{ns}}$ \\
\hline ESP & $-0.13^{\text {ns }}$ & $-0.40^{\mathrm{ns}}$ & $0.02^{\mathrm{ns}}$ & $0.43^{\mathrm{ns}}$ & $-0.08^{\mathrm{ns}}$ \\
\hline EC & $-0.20^{\text {ns }}$ & $-0.01^{\mathrm{ns}}$ & $0.11^{\mathrm{ns}}$ & $0.08^{\mathrm{ns}}$ & $0.33^{\text {ns }}$ \\
\hline
\end{tabular}

1. OC - Organic Carbon, TN-total nitrogen, C:N - Carbon nitrogen ratio, $\mathrm{Ca}$ - Calcium, Mg - Magnesium, $\mathrm{Na}$ - Sodium, $\mathrm{K}$ - Potassium, pH - Soil pH, EXA - exchangeable acidity, SAR - Sodium adsorption ratio, ESP - exchangeable sodium percentage, EC - electrical conductivity.

2. MAD - Macro Aggregate dry, MAW - Macro aggregate wet, WSI - water stability index, DR - dispersion ratio, ASC aggregate silt + clay.

3. * - Significant at $5 \%,{ }^{* *}$ - significant at $1 \%,{ }^{* * *}$ - significant at $0.1 \%$ and ns - not significant. 
Agric. Biol. J. N. Am., 2013, 4(4): 234-242

Table 3 . Mean water stability index (WSI\%), dispersion ratio (DR\%) and aggregate silt + clay (ASC \%) contents of the soil as affected by tillage systems at $0-15$ and $15-30 \mathrm{~cm}$ soil depths

\begin{tabular}{lccc}
\hline Treatment & WSI (\%) & DR (\%) & ASC (\%) \\
\hline $0-15 \mathrm{~cm}$ & & & 7.30 \\
NT & 69.67 & 76.18 & 6.30 \\
RT & 54.63 & 80.82 & 4.80 \\
CT & 44.27 & 83.88 & NS \\
LSD $(0.05)$ & 12.526 & NS & \\
$15-30 \mathrm{~cm}$ & & & 6.00 \\
NT & 65.67 & 81.34 & 5.50 \\
RT & 54.24 & 83.24 & 5.00 \\
CT & 47.14 & 87.52 & NS \\
LSD $(0.05)$ & 12.802 & 5.231 & \\
\hline
\end{tabular}

${ }^{1}$ NT-no till, RT-reduce till, CT-Conventional

${ }^{2}$ NS- not significant at $p \leq 0.05$

The EC and SAR of the soil did not correlate with aggregate stability indices at both surface $(0-15 \mathrm{~cm})$ and sub surface $(15-30 \mathrm{~cm})$ soil depths. However, ESP of the soil correlated well (negatively) with macro aggregates of wet aggregates (MAW) and WSI at the surface $(0-15 \mathrm{~cm})$ soil depth (Table 2). Similar results were obtained by Chappell et al. (1999). Further, although higher carbon nitrogen ratio (C:N) is an indication of poor quality organic matter (Lal, 1997), treatments with higher C:N particularly at surface $(0-15 \mathrm{~cm})$ soil depth (NT and RT) had better stability of aggregates compared to the CT treatment with lower C:N. Tisdall and Oades (1982) reported that materials with higher $\mathrm{C}: \mathrm{N}$ provides persistent binding agents and good fungal development that promotes aggregation. This explains why $\mathrm{C}: \mathrm{N}$ of the soil fairly correlated with most stability indices although not significantly $(p<0.05)$ in most cases (Table 2).

Furthermore, volumetric moisture content $(\Theta v)$ of the soil correlated significantly $(p<0.05)$ with dry and

wet aggregate stability ( MAD, MAW and ASC \%) particularly at surface $(0-15 \mathrm{~cm})$ soil depth (data not shown). This could partly be explained by the fact that when dry aggregates were allowed to saturate in contact with water at atmospheric pressure, air bubbles are entrapped inside the aggregate and are compressed by water pulled into it by capillarity, until the air bubbles burst out of the partially wetted aggregate, with its partial disintegration (Kemper and Koch, 1966). The wetter the aggregate, the smaller the effect of air bubble entrapment, which may be expressed in a high positive correlation between moisture content and aggregate stability (particularly aggregate stability in water). Similar observations were made by Milton da Viega et al. (2009). Generally, on average, values of WSI (\%) and ASC (\%) decreased with depth, while those of DR increased with depth irrespective of tillage methods (Table 3 ). 
Agric. Biol. J. N. Am., 2013, 4(4): 234-242

Table 4: Percentage sand, silt and clay contents of individual treatment plots for surface $\mathbf{0 - 1 5} \mathbf{c m}$ soil layer

\begin{tabular}{ccccc}
\hline Treatments & (\% sand) & (\% silt) & (\% clay) & Textural class \\
\hline NT $0-15 \mathrm{~cm}$ & & & & \\
1 & 72.1 & 18.2 & 9.7 & Sandy loam \\
2 & 67.1 & 20.7 & 12.2 & Sandy loam \\
3 & 69.6 & 20.7 & 9.7 & Sandy loam \\
4 & 69.6 & 18.2 & 12.2 & Sandy loam \\
5 & 69.6 & 20.7 & 9.7 & Sandy loam \\
RT & & & Sandy loam \\
1 & 69.6 & 18.2 & 12.2 & Sandy loam \\
2 & 72.1 & 20.7 & 7.2 & Sandy loam \\
3 & 69.6 & 20.7 & 9.7 & Sandy loam \\
4 & 69.6 & 18.2 & 12.2 & Sandy loam \\
5 & 67.1 & 20.7 & 12.2 & Sandy loam \\
CT & & & 12.2 & Sandy loam \\
1 & 72.1 & 15.7 & 9.7 & Sandy loam \\
2 & 72.1 & 18.2 & 12.2 & Sandy loam \\
4 & 69.6 & 18.2 & 9.7 & Sandy loam
\end{tabular}

\section{CONCLUSION}

The study revealed that conventional tillage (CT) decreased aggregate stability of the soil over time. This was reflected by decreased mean weight diameter of dry (MWDD) and wet (MWDW) aggregates, lower water stability index (WSI), and higher dispersion ratio (DR) of the CT treatment. The NT treatment on the other hand, had best of structural stability indices (except MWDD) followed by the RT treatment .The structural stability of the soil was found to have best relationship with organic carbon (OC), potassium (K) and total nitrogen (TN) content of the soil. In general, however, structural stability of the soil decreased with depth irrespective of tillage method. As revealed by structural stability indices, the conservation tillage (NT and RT) practices offers significant advantage over the conventional (CT) practice in promoting better structural stability of the soil studied for sustainable agriculture.

\section{REFERENCES}

Barzegar, A.R., Asoodar, M.A., Eftekhar, A.R. and Herbert, S.J. 2004. Tillage effects on soil physical properties and performance of irrigated wheat and Clover in semi arid region. J. Agron. 3(4): $237-242$.

Bryan, R.B., Govers, G. and Poesen, J. 1989. The concept of soil erodibility and some problems of assessement and application. Catena 16: 393- 412.

Chappell, N.A., Ternan , J.L. and Bidin, K. 1999. Correlation of physicochemical properties and suberosional land forms with aggregate stability variations in a tropical Ultisol disturbed by forestry operations. Soil Tillage Res. 50: 55-71.
Chiroma, A.M., Foloronso, O.A., and Alhassan, A.B. 2006. The effects of land configuration and woodshavings mulch on the properties of a sandy loam soil in Northeast Nigeria 2. Changes in physical propertie s. Tropicultura 24(1) : 33-38.

Folorunso, O.A. 1986. Distribution of field-measured steady-state infiltration rate for a Borno State soil. Annals of Borno 3:193-204.

Franzlsuebbers, A.J. 2002. Water infiltration and soil structure related to organic matter and its stratification with depth. Soil Tillage Res. 66 :197-205.

Golchin, A. and Asgari, H. 2008. Land use effect on soil quality indicators in north eastern Iran. Australian J. Soil Res. 46 (1): 27-36.

Grema A.K. and Hess, T.M. 1994. The impact of changing rainfall patterns on the efficiency of rainfall utilization in pearl millet - cowpea intercropping systems in north east Nigeria. Aspects of Applied Biolo gy 38:231 - 238 .

Kemper,W.D. 1965. Aggregate stability. In: Methods of soil Analysis part 2 (ed. C . A. Black). Society of Agro nomy, Madison. Pp 511-519.

Kemper,W.D. and Chepil, W.S. 1965. Size distribution of A ggregates. In : C.A.Black (Ed.). Methods of soil Analy sis, part 2. ASA, Madison. Pp 499-510.

Kemper, W.D. and Koch, E.J. 1966. Aggregate stability of soils from western United State and Canada. Washington, Agric. Res. Serv./USDA, Technical bulletin, 1355. p52.

Lal, R. 1997. Long term tillage and Maize monoculture effects on tropical Alfisol in western Nigeria I. Crop yield and soil physical properties. Soil tillage Res. 42:145- 160. 
Malquori, A.R. and Cecconi, S. 1962. Determinazione Seriale del Terreno. Agrochimica 6.Pp 198-204.

Mbagwu, J.S.C. and Auerswald, K. 1999. Relationship of percolation stability of soil aggregates to land use, selected soil properties, structural indices and simulated rainfall erosion. Soil Tillage Res. 50:197206.

Mbagwu, J.S.C. and Bazzoffi, P. 1989. Properties of soil aggregates as influenced by tillage practices. Soil Use and Management. 15: 180-188.

Middleton, H.E. 1930. Properties of soils which influence so il erosion. United States Department of Agriculture Technical Bulletin Number 178.

Milton da Veiga, Dalvan, J.R. and Jose, M.R. 2009. Aggregate stability as affected by short and longterm tillage systems and nutrient sources of a Hapludox in Southern Brazil. R.Bras.Ci. Solo 33:767777.

Osuji, G.E. and Onweremadu, E.U. 2007. Structural stability of Dystic Nitisol in relation to some Edaphic properties under selected land uses. Nature and Science 5 (4): 7-13.

Page, A.L., Miller, R.H. and Keeney, D.R. 1982. Methods of soil Analysis, part 2. Chemical and mineralogical properties. Agronomy monograph No. 9. ASA - SSSA. Madison,WI.
Piccolo, A. and Mbagwu, J.S.C. 1999. Role of Gydrophobic components of soil organic matter on soil aggregate stability. Soil Sci. Soc. Am. J. 63: 18011810.

Pikul, J.L. and Aase, J.K. 1995. Infiltration and soil properties as affected by annual cropping in the Northern Great Plains. Journal Agron. 87(4): 654-662.

Rayar, A.J. 1984. University of Maiduguri farm development planning report for faculty of Agriculture, Annex A; Soil Survey Details.

Singh, A. and Kaur, J. 2012. Impact of conservation tillage on soil properties in rice-wheat cropping system. Agric. Sci. Res. J. 2(1): $30-41$.

Six, J., Paustian, K., Elliot, E.T. and Combrink, C. 2000a. Soil structure and organic matter 1. Distribution of aggregate size classes and aggr egate associated carbon. Soil Sci. Soc. Am. J. 64: 681 -689 .

Statistix 8.0 2005. Ststistix 8.0 (Version 2005), statistix for windows analytical Software, USA.

Tedescchi, A. 2000. Influence of soil sample conditioning in the evaluation of soil structure stability as affected by irrigation with saline water. Ital. J. Agron. 3(2): 117-122.

Tisdall, J.M., Oades, J.M. 1982. Organic matter and water stable aggregates in soils. J. Soil Sci. 33: 141-163. 